\title{
STUDENTS' INTEREST IN PURSUING EDUCATION: EVIDENCE FROM THE PERSPECTIVE OF LEARNING MOTIVATION AND PARENTS' SOCIO-ECONOMIC STATUS
}

\author{
Mohamad Muspawi ${ }^{1}$, Lusi Anesa ${ }^{2}$ \\ 1,2FKIP Universitas Jambi \\ 1,2Mendalo darat, Kec. Jambi Luar Kota, Kab. Muaro Jambi, Jambi \\ Email: muspawi01@gmail.com ${ }^{1}$,Anesa19@gmail.com²
}

\begin{abstract}
:
This research aimed to find out the effect of learning motivation and parents' socioeconomic status on the students' interest to continue study in master degree at Education Administration Study Program in Jambi University. This research used quantitative approach with survey research design. The population was the students of Education Administration Study Program batch 2015 and 2016 in Jambi University which consisted of 71 students. This study used the entire population as sample to obtain more accurate and reliable data. Closed questionnaire using Likert scale was the instrument of collecting data. The data analysis technique used was descriptive statistical analysis. The findings indicated that there was influence of learning motivation on the students' interest to continue study in master degree, there was influence of parents' socioeconomic status on the students' interest to continue study in master degree, and there was influence of learning motivation and parents' socioeconomic status toward the students' interest to continue study in master degree.
\end{abstract}

\begin{abstract}
Abstrak:
Penelitian ini bertujuan untuk mengetahui pengaruh motivasi belajar dan status sosial ekonomi orang tua terhadap minat belajar siswa untuk melanjutkan studi S2 di Program Studi Administrasi Pendidikan Universitas Jambi. Penelitian ini menggunakan pendekatan kuantitatif dengan desain penelitian survei. Populasi penelitian ini adalah mahasiswa Program Studi Administrasi Pendidikan angkatan 2015 and 2016 di Universitas Jambi yang terdiri dari 71 mahasiswa. Penelitian ini menggunakan seluruh populasi sebagai sampel untuk mendapatkan data yang lebih akurat dan dapat diandalkan. Kuesioner tertutup menggunakan skala Likert adalah instrumen pengumpulan data. Teknik analisis data yang digunakan adalah analisis statistik deskriptif. Temuan menunjukkan bahwa ada pengaruh motivasi belajar terhadap minat siswa untuk melanjutkan studi di tingkat magister, ada pengaruh status sosial ekonomi orang tua terhadap minat siswa untuk melanjutkan studi di tingkat magister, dan ada pengaruh motivasi belajar dan status sosial ekonomi orang tua terhadap minat siswa untuk melanjutkan studi di tingkat master.
\end{abstract}

\section{Keywords:}

Interest in Continuing Study, Learning Motivation, Parents' Socio-Economic Status

How to Cite: Muspawi, M., \& Anesa, L. (2020). Students' Interest in Pursuing Education: Evidence from The Perspective of Learning Motivation and Parents' Socio-Economic Status. Lentera Pendidikan : Jurnal Ilmu Tarbiyah dan Keguruan, 23(1), 158-172. https://doi.org/10.24252/lp.2020v23n1i13. 


\section{INTRODUCTION}

Indonesia can be considered as one of the countries that has the most populated human resource in the world. Therefore, Indonesia has the potential to become a welldeveloped country and does not depend on other countries. This is also further supported by abundant natural resources. Human resources and abundant natural resources will be more advanced if it is able to be balanced with quality of human resources. Because of that, the role of education is very important in producing qualified human resources that are of Spiritual Quality (SQ), Emotional Quality (EQ) and Intellectual Quality (IQ).

Education is one way to build the quality of human being (Muspawi \& Claudia, 2018: 180). On the other hand, education is one of the main instruments in developing the potential or ability of human resources as the next generation of a nation that can make quality of human resources. In this case, the government always strives to be able to produce quality of human resources by doing many things. One of them is through the development program of state and private higher education institutions. Law Number 12 year 2012 about higher education in article 1 paragraph (1) states that after secondary education, the next level of education is higher education in which there are Diploma, Bachelor, Master, Doctoral, Professional, and specialist programs organized based on the nation's culture. Thus, if everyone who continues their education to a higher education level, each person can develop skills and gain in-depth knowledge based on their interests of study programs by their potential, it will become an important provision to be more competitive in the world of work.

Markum (2007: 9) explains that the implementation of higher education is one of the forms of efforts in order to prepare young people with academic abilities in a professional manner who can develop and apply and create science, technology, and art. With the large contribution of higher education through human resources that are prepared reliably and able to compete in the face of globalization.

Continuing studies to a higher level are everyone's hope. Some people will choose to work after completing their studies and holding a bachelor degree while some others choose to continue their studies to master degree. In many parts of the world especially in Indonesia, there are already many people who have carried a bachelor degree. Thus, the current situation can be imagined how difficult and competitive it is to get a job.

Choosing to continue studying in master degree can give more points compared to bachelor graduates. Many argue that a bachelor is not much different from master degree because in the world of work for both levels of graduation when starting a career at the same time, both will have the same amount of salary. However, to have in-depth knowledge of the subjects of interest, a graduate master degree is considered qualified in this regard. By deciding to continue to graduate school education will also train the character to be more mature so that they can become excellent candidates in the world of work. In many companies or government institutions, the graduates of master degree who succeed in finding work usually get higher-level positions. This is also supported by the results of research that reveal professionals with a master degree on average can contribute with better performance compared to bachelor graduate. A person continuing 
his study to master degree is driven by several factors, including the desire to improve abilities, the fulfillment of welfare, and readiness to compete in finding work.

Education administration study program includes as a new study program at Faculty of Teacher Training and Education, University of Jambi. Even so, Education Administration Study Program is always interesting from year to year since it was first opened. Moreover, the peak experienced a significant increase in 2018 compared to previous years. Thus, it can be ascertained that the number of graduated students will be increased causing job acquisition will be more competitive.

Master degree in administration or management education with the improvement of skills, qualities and competitiveness will be more counted because the graduates can be considered more professional academically in the field. However, when students have undertaken undergraduate study and get a bachelor degree (S. Pd), apparently not many students will continue at the next level of education, namely postgraduate (master degree). This is very different from the situation when registering for a Diploma or undergraduate applicants. The government even provided three procedures in order to enter state tertiary institutions, namely registration through SNMPTN, SBMPTN, and the Independent Exam. If the participants of the state higher education entrance exam do not pass the established test path, many of them choose private universities. This indicates that the number of applicants for diploma and scholar is higher compared to master. Nevertheless, there are still some graduates who continue their studies to master degree.

Based on the initial dialogue conducted on 30 students of Education Administration Study Program batch 2015 and 2016 on January 23-25, 2019 the following data were obtained:

Table 1. The students' Interest of Academic Year 2015 and 2016 to Continue Study Master Degree

\begin{tabular}{cccccc}
\hline Batches & $\begin{array}{c}\text { Amount } \\
\text { of } \\
\text { students }\end{array}$ & \multicolumn{2}{c}{$\begin{array}{c}\text { Students Who are } \\
\text { Interested in Continuing to } \\
\text { Master Degree }\end{array}$} & \multicolumn{2}{c}{$\begin{array}{c}\text { Students Who are Not } \\
\text { Interested in Continuing } \\
\text { to Master Degree }\end{array}$} \\
\cline { 2 - 6 } & & Students & $\mathbf{\%}$ & Students & \% \\
\hline 2015 & 20 & 2 & 10 & 18 & 90 \\
\hline 2016 & 10 & 3 & 30 & 7 & 70 \\
\hline
\end{tabular}

Based on the table it is illustrated that the interest of students to continue their master degree studies is still very low. Table 1 shows the results that batch 2015 is $10 \%$ and batch 2016 is only $30 \%$ of students who have interest in continuing their study to master degree, the rest chose not to continue. The students' low interest in Education Administration Program Study to continue their study to master degree due to various reasons including, being lazy to study again because they feel studying during bachelor degree has drained their mind and energy, Feeling alone go back to college to continue master degree, and also support from parents in economic matters considering the cost of master degree courses are not cheap. As reported by Ekpo \& Ajake (2013) that the socioeconomic status of a family influences one's education. Someone's interest in something or 
desire for something is an understanding of the term interest. So students who are interested in continuing their higher education will always try to dig up information and pay attention to the tertiary institution that will be their next destination. Factors that influence interest in continuing the study of subsequent levels are influenced by factors from outside as well as from within the students themselves. Factors from within referred to, according to Jumarin (1994: 32) include learning motivation, learning achievement, intelligence levels, talents, circumstances, physical, attitudes, and work expectations. While external factors are the socio-cultural environment, socioeconomic factors, school friends, and so forth. With the motivation to learn, students feel compelled to study harder. The reflection of high motivation to learn is from the tenacity and perseverance of students in learning and feel hopeless when facing difficulties to achieve success. It can foster the students' interest to continue their studies to master degree which also needs to be supported by people in their environment. Lack of learning motivation can lead to a suboptimal interest in students to continue their studies to master degree. According to Umma \& Margunani (2015), the students' interest in continuing education is influenced by learning motivation. The same study was also conducted by Farmesa, Hasmunir, \& Abdul (2017). The results of their study indicated that there was positive influence between the variables of learning motivation on the students' interest in continuing their master degree education.

Socio-economic condition of the students' parents also influences their interest to continue to higher education apart from the lack of their learning motivation. Gerungan (2009: 196) stated that socio-economic role of a family is very important to arouse the interest of the students to continue their education to the master degree. In addition, Idi (2010: 18) also stated that the assurance and support of parents make their child has wider opportunities to develop knowledge and various other potential self-skills. A research conducted by Ekpo \& Ajake (2013) also found that education of a child is influenced by the socioeconomic status of his/her family. With a sufficient level of parental economy in a family, a child has the opportunity to have wider opportunities to develop a variety of skills that he/she cannot develop if there is no infrastructure.

The position held by parents is seen from the economic conditions and social conditions that are associated with socioeconomic status in the community. Attitudes and levels of parental aspirations towards their children's education are influenced by parents' socioeconomic conditions. Parents who are considered to have high economic and social status in society have more attention to their children's education. Thus, the low socioeconomic status of parents can hamper the students' interest to continue their studies to a higher level of education. This is because the costs used to continue study to master degree is expensive. With good family economic conditions, the students who are in these conditions will not feel the lack of all educational needs so that it can arouse interest and motivation to continue their education. 


\section{RESEARCH METHOD}

The research approach used was quantitative approach with a survey method. According to Creswell \& Guetterman (2018), one of the main characteristics of quantitative research was gathering numerical data from a large number of people who use instruments with predetermined questions, linking variables using statistical analysis and comparing the results of research with previous predictions. The population of this research was the students of Education Administration Study Program batch 2015 and 2016 in Jambi University which consisted of 71 students. Darmawan (2014: 137) stated that population is a source of data in certain studies that have a large amount and area. Prasetyo \& Jannah (2014: 119) also stated that the sample is part of the population that wants to be studied. This study used the entire population as sample to obtain more accurate and reliable data. In this study, the researchers took special respondents from the students of Education Administration Study Program batch 2015 and 2016 in Jambi University because this research was related to the interest in continuing studies. Respondents chosen were the students who had entered the final semester and had taken thesis course so that the students' further plans were known after completing the study or getting bachelor degree later.

Data were collected through questionnaire. According to Sugiyono (2016: 142) questionnaire was data collection which was done by giving a set of questions to the respondents to answer. In this case, the instrument used to reveal the data variables of this study was closed questionnaire using Likert scale, which contained a list of questions that expect respondents to choose one alternative answer from each question that had been provided.

The analysis technique began with descriptive statistical analysis, which aimed to find out the value of the tendency of the research data by describing the data of research variables such as mean, median, range, and standard deviation. To describe the variables of learning motivation, parents' socioeconomic status and students' interest to continue their studies to master degree, the mean guidelines were used, which were consulted with the table criteria or mean category. In practice, the processing of statistical data was carried out through computer assistance with the SPSS 22.0 application program. Using the SPSS application facilitated the researchers and saved time in the research process. Furthermore, the analysis requirements test which consisted of normality test, linearity test, heteroscedasticity test, and multicollinearity test was done. After the prerequisite tests had been met then testing the hypothesis that had been submitted. The analytical method used for testing the first and second hypotheses was the simple linear regression analysis method (partial effect), while the analytical method used for testing the third hypothesis was the multiple regression analysis method (simultaneous effect).

\section{RESULT AND DISCUSSION}

The researcher presented the results of testing the hypothesis in this section. Hypothesis testing was carried out to see the significance of the influence of learning motivation and the parents' socioeconomic status partially and simultaneously on the 
interest in continuing their studies to master degree. Partial hypothesis testing was performed using the t-test, while simultaneous hypothesis testing uses the F-test as described in the following paragraphs:

\section{Simple Regression Analysis with t-test Partially}

\section{Learning Motivation Regression Test (X1) toward the Interest to Continue Study in Master degree (Y)}

The hypothesis proposed in the partial test (t-test) of learning motivation toward the interest to continue the study in master degree was as follows:

$\mathrm{H}_{\mathrm{a}}$ : Learning motivation partially had a significant influence on the interest to continue study in master degree.

$\mathrm{H}_{0}$ : Learning motivation partially did not have a significant influence on the interest to continue study in master degree.

The statistical hypotheses tested were as follows:

$\mathrm{H}_{\mathrm{a}}$ is accepted if the value of sig. $<0.05$

$\mathrm{H}_{0}$ is accepted if the value of sig. $>0.05$

The results of the coefficient of determination of learning motivation (X1) on the interest in continuing study to master degree $(\mathrm{Y})$ were as follows:

Tabel 2. The coefficient of Learning Motivation Determination (XI) Toward the Interest in to Continue Study in Master Degree.

\begin{tabular}{llll}
\hline Model Summary & & & \\
\hline Model & R & R Square & Adjusted R Square \\
\hline 1 & $.750^{\text {a }}$ & .562 & .556 \\
\hline
\end{tabular}

a. Predictors: (Constant), Learning motivation

Based on the result of the coefficient of determination, it appeared that the value of $\mathrm{R}$ square was 0.562 . This meant that the independent variable, learning motivation, contributed to the dependent variable, namely the interest to continue study with $56.2 \%$.

Tabel 3. The Result of Partial Test (t-test) Learning Motivation

Coefficients ${ }^{\mathrm{a}}$

\begin{tabular}{clccccc}
\hline \multirow{2}{*}{ Model } & \multicolumn{2}{c}{$\begin{array}{c}\text { Unstandardized } \\
\text { Coefficients }\end{array}$} & $\begin{array}{c}\text { Standardized } \\
\text { Coefficients }\end{array}$ & T & Sig. \\
\cline { 3 - 7 } & & B & $\begin{array}{c}\text { Std. } \\
\text { Error }\end{array}$ & Beta & & \\
\hline 1 & & 14.996 & 3.802 & & 3.944 & .000 \\
\cline { 2 - 7 } & (Constant) & .559 & .059 & .750 & 9.408 & .000 \\
& Learning & & & & & \\
\hline
\end{tabular}

a. Dependent Variable: Interest in continuing study 
The simple regression equation used was $\mathrm{Y}=\mathrm{a}+\mathrm{bX}$

Information:

$\mathrm{Y}=$ Criterium

$\mathrm{a}=$ Constant number

$\mathrm{b}=$ coefficient number

$\mathrm{X}=$ Predictor (Independent variable which had a certain value)

Based on table 3, it was known that the simple regression equation obtained was $Y$ $=14.996+0.559 \mathrm{X} 1$. The influence of learning motivation on the students' interest to continue study in master degree was 0.559 with Sig. 0.000 , which meant each percent of learning motivation increased the students' interest to continue study in master degree with $0.559 \%$. It was also found that t-test was higher than t-table which was $9.408>1.995$. It meant that learning motivation had positive influence on the students' interest to continue study in master degree. The $t_{\text {table }}$ was obtained by calculating $\mathrm{df}=\mathrm{n}-2$. From the calculation, it could be seen that in the distribution of $t_{\text {table }}$ value in column $\mathrm{df} 0.05$ and in 69 column, the $t_{\text {table }}$ value of 1.669 is obtained.

In order to see the influence between variables, it was necessary to see the significant value which was below the alpha value of 0.05 or $0.000<0.05$. It could be concluded that the variable of learning motivation (X1) had a significant influence on the students' interest to continue their study in master degree $(\mathrm{Y})$.

\section{Regression Test of Parents' Socio-Economic Status (X2) towards The Interest in Continuing Studies to Master's Degree (Y)}

The hypothesis proposed in the partial test (t-test) of the socio-economic status of parents toward the interest to continue study in master degree was as follows:

$\mathrm{H}_{\mathrm{a}}$ : The socio-economic status of parents partially had a significant influence on the students' interest to continue study in master degree.

$\mathrm{H}_{0}$ : Parents' socio-economic status partially did not have a significant influence on the students' interest to continue study in master degree.

The statistical hypotheses tested were as follows:

$\mathrm{H}_{\mathrm{a}}$ was accepted if the value of sig. $<0.05$

$\mathrm{H}_{0}$ was accepted if the value of sig. $>0.05$

The result of the determination coefficient of the parents' socio-economic status (X2) on the students' interest to continue study in master degree $(\mathrm{Y})$ was presented in table 4.

Table 4. The Results of The Determination Coefficient of The Parents' Socio-Economic Status (X2) on The Students' Interest to Continue Study in Master Degree (Y)

Model Summary

\begin{tabular}{ccccc}
\hline Model & R & R Square & $\begin{array}{c}\text { Adjusted R } \\
\text { Square }\end{array}$ & $\begin{array}{c}\text { Std. Error of the } \\
\text { Estimate }\end{array}$ \\
\hline 1 & $.430^{\mathrm{a}}$ & .185 & .173 & 8.14579 \\
\hline
\end{tabular}

a. Predictors: (Constant), social status 
Based on the result of the determination coefficient, it showed that $\mathrm{R}$ square was 0.185. This meant that the independent variable, the parents' socioeconomic status, contributed to the dependent variable, namely the students' interest to continue study in master degree with $18.5 \%$.

Table 5. Partial Test Result (t-test) of Parents' Socio-Economic Status

\section{Coefficients $^{\mathrm{a}}$}

\begin{tabular}{|c|c|c|c|c|c|c|}
\hline & \multirow{2}{*}{ Model } & \multicolumn{2}{|c|}{$\begin{array}{c}\text { Unstandardized } \\
\text { Coefficients }\end{array}$} & \multirow{2}{*}{$\begin{array}{c}\begin{array}{c}\text { Standardized } \\
\text { Coefficients }\end{array} \\
\text { Beta }\end{array}$} & \multirow[t]{2}{*}{$\mathbf{T}$} & \multirow[t]{2}{*}{ Sig. } \\
\hline & & B & $\begin{array}{l}\text { Std. } \\
\text { Error }\end{array}$ & & & \\
\hline \multirow[t]{2}{*}{1} & (Constant) & 32.669 & 4.506 & & 7.250 & .000 \\
\hline & $\begin{array}{l}\text { Socio-economic } \\
\text { status }\end{array}$ & .705 & .178 & .431 & 3.970 & .000 \\
\hline
\end{tabular}

a. Dependent Variable: interest in continuing study

The simple regression equation used was $\mathrm{Y}=\mathrm{a}+\mathrm{bX}$

Information:

$\mathrm{Y}=$ Criterium

$\mathrm{a}=$ Constant number

$\mathrm{b}=$ coefficient number

$\mathrm{X}=$ Predictor (Independent variable which has a certain value)

Based on the table 5 , it described that the simple regression equation obtained was $\mathrm{Y}=32.666+0.705 \mathrm{X} 2$. The influence of parents' socio-economic status on students' interest in to continue study in master degree was 0.705 on Sig. 0.000 . It could also be seen that the $t$-value was greater than the $t$-table value which was $3.970>1.995$. ttable was obtained by $\mathrm{df}=\mathrm{n}-2$ calculation. In addition to see the influence between variables could also be seen from the significance value that was less than the alpha value of 0.05 or 0.000 $<0.05$. Thus, it could be concluded that the parents' socio-economic status variable (X2) had significant influence on the students' interest to continue study in master degree (Y).

\section{Analysis of Multiple Regression with The Simultaneous F-Test}

The F-test was used to see the significant influence that independent variable had on the dependent variable. 
Table 6. The Result of Multiple Regression Analysis

\begin{tabular}{|c|c|c|c|c|c|c|}
\hline \multicolumn{7}{|c|}{ Coefficients $^{a}$} \\
\hline \multicolumn{2}{|c|}{ Model } & \multirow{2}{*}{\multicolumn{2}{|c|}{$\begin{array}{l}\text { Unstandardized } \\
\text { Coefficients }\end{array}$}} & \multirow{3}{*}{$\begin{array}{l}\text { Standardized } \\
\text { Coefficients } \\
\text { Beta }\end{array}$} & \multirow{3}{*}{$\mathrm{T}$} & \multirow{3}{*}{ Sig. } \\
\hline & & & & & & \\
\hline & & B & Std. Error & & & \\
\hline \multirow[t]{2}{*}{1} & (Constant) & 32.669 & 4.506 & & 7.250 & .000 \\
\hline & $\begin{array}{l}\text { Socio-economic } \\
\text { status }\end{array}$ & .705 & .178 & .431 & 3.970 & .000 \\
\hline
\end{tabular}

Based on the table 6 , it could be seen that the multiple regression analysis equation was $\mathrm{Y}=6.244+0.514 \mathrm{X} 1+0.467 \mathrm{X} 2$. Then it could be seen that the constant value was positive with 6.244. This showed that there was a direct correlation between the variables $\mathrm{X}$ to $\mathrm{Y}$. If $\mathrm{X} 1$ and $\mathrm{X} 2$ value was 0 , then $\mathrm{Y}$ value was;

Table 7. Simultaneous Test Result (F-Test)

\begin{tabular}{llllll}
\hline ANOVA $^{\mathbf{b}}$ & \multicolumn{5}{l}{ Mean } \\
\hline Model & $\begin{array}{l}\text { Sum of } \\
\text { Squares }\end{array}$ & Df & $\begin{array}{l}\text { Square } \\
\text { Sq }\end{array}$ & Sig. \\
\hline 1 Regression & 3595.503 & 2 & 1797.751 & 60.426 & $.000^{\text {a }}$ \\
\hline Residual & 2023.089 & 68 & 29.751 & & \\
\hline Total & 5618.592 & 70 & & & \\
\hline a. Predictors: (Constant), socio-economic status, learning motivation \\
\hline \multicolumn{4}{l}{ b. Dependent Variable: interest in continuing study } \\
\hline
\end{tabular}

This statistical $\mathrm{F}$ test described the calculated $\mathrm{F}$ value was greater than the $\mathrm{F}$ table value with $60.426>3.13$. $\mathrm{F}$ table value could be obtained from the df1 value $=\mathrm{k}-1=3-1$ $=2$. Then, $\mathrm{df} 2$ value was $\mathrm{n}-\mathrm{k}=71-3=68$. The table $\mathrm{F}$ value was 3.13 . To find out the influence between variables simultaneously, it could also be seen from the significance value in table 7 that the significance value was lower than 0.05 i.e. $0.000<0.05$. Thus, it could be concluded that the variables of learning motivation and parents' socio-economic status had significant influence on the students' interest to continue study in master degree.

Based on these results, it presented that the influence of the first independent variable was the value of learning motivation which was greater than the second independent variable, namely the parents' socio-economic status to the value of continuing study to the master degree. Nevertheless, the two independent variables had positive influence on dependent variable which increased the value of students' learning motivation in master degree. Socioeconomic status of the parental figure, the value of interest in continuing study in master degree level would also increase. 


\section{Coefficient of Determination}

Tabel 8. The Result of Simultaneous Coefficient of Determination $\left(\mathrm{R}^{2}\right)$

\begin{tabular}{ccccc}
\hline \multicolumn{4}{c}{ Model Summary } \\
\hline Model & $\mathbf{R}$ & R Square & $\begin{array}{c}\text { Adjusted R } \\
\text { Square }\end{array}$ & Std. Error of the Estimate \\
\hline 1 &, $800^{\mathrm{a}}$ &, 640 &, 629 & 5,454 \\
\hline a. Predictors: (Constant), socio-ecomic status, learning motivation
\end{tabular}

Based on the results of the determination coefficient, it showed that $\mathrm{R}$ square value was 0.640 . This meant that the independent variable contributed to the dependent variable for $64.0 \%$ and the other $36.0 \%$ was influenced by other factors.

This research described the influence of learning motivation and socio-economic status on the students' interest to continue study in master degree of Education Administration Study Program of Teacher Training and Education Faculty in Jambi University. There were three problems which were needed to be answered through the research that had been done. Here was the following explanation of the various results that had been analyzed previously.

\section{The Influence of Learning Motivation on The Students' Interest to Continue Study in Master Degree of Education Administration Study Program in Jambi University}

Learning motivation was the driving force of students to study hard. High learning motivation was reflected in students' perseverance and tenacity in learning. High learning motivation could also be seen in students who did not easily give up on their study when facing difficulties in the process of achieving success. Motivation always determined the intensity of someone's effort in learning and motivation related to the goal. In the learning process, motivation was really needed because someone without learning motivation would find it difficult to do any kinds of learning activities. This was the sign where the activity did not have something that individual want to work toward. It was important to note that not everything that was interesting for general public would have the same effects for everyone.

The research result showed that t-test for students' learning motivation and interest to continue study in master degree was 9.408 compared to t-table that showed only 1.995 . Therefore, $\mathrm{H} 0$ equation was declined resulting in partially significant impact between learning motivation (X1) to the motivation in continuing study to master degree (Y). This findings related to the research result conducted by Tampubolon in Khairani (2013: 137) who stated defined interest as a combination of desire and will could develop only if there was motivation. In addition, Khairani (2013) also mentioned that the factors influence the students' interest were 1) factor Inner urge, 2) Factor of social motive, and 3) Emotional factor.

Umma \& Margunani (2015) in their research stated that there was an influence of learning motivation on students' interest to continue study. This was indicated by the 
results of the study that the influence of learning motivation was $46.38 \%$. In addition, the research conducted by Sunarno (2017) showed that there was a significant influence of learning motivation on interest to continue study. Another study by Sunarno (2017) also showed a significant influence of learning motivation on the interest in continuing studies.

Based on this explanation, it could be concluded that there was a significant influence between learning motivation on the students' interest in continuing studies to master degree. The higher the students' learning motivation is, the more interest them to continue study.

\section{The Influence of Parents' Socio-Economic Status toward Students' Interest to Continue Study in Master Degree of Education Administration Study Program in Jambi University}

Based on the research finding, it could be seen that the influence of parents' socioeconomic status on students' interest in continuing studies was 0.705 with Sig. 0.000. It was also shown that ttest was higher than ttable which was only 3.970>1.995. In addition, it was known that the effect between variables could also be seen from the significance value that was less than alpha value 0.05 or $0.000<0.05$. Thus, it could be concluded that the parents' socio-economic status variable (X2) had significant influence on the students' interest in continuing study to master degree $(\mathrm{Y})$.

The results of this study were supported by Gerungan (2009: 196) who stated that the role of economic conditions played such an important role for children's education. The problem of parents' socio-economic status ultimately caused problems for parents to determine alternative options for their children's to continue their studies. A research conducted by Ekpo \& Ajake (2013) showed that the socio-economic status of a family affected the education of an individual in a way that a person with a good family economic condition would find it easy to fulfil education needs. Thus, the students' interest to continue study would increase.

The research result was also in line with the study conducted by Kharisma \& Latifah (2015), they concluded that the parents' socio-economic status affected $16.81 \%$ of the students' interest to continue study. Following up with the research conducted by Hanifah, Rusdianti, \& Pujiati (2018) also showed that there was a direct socio-economic influence on the students' interest to continue study for (9.5\%). Another study conducted by Fitriani (2013) also showed the same result that the socio-economic status of parents affected $25.50 \%$ of the students' interest to continue study. Therefore, it could be concluded that there was significant influence of parents' socio-economic status on the students' interest to continue study. 
The Influence of Learning Motivation and The Parents' Socio-Economic Status toward The Students' to Continue Study in Master Degree of Education Administration Study Program in Jambi University

The result of this research showed that the significance was lower than 0.05 , which was $0.000<0.05$. Hence, it could be concluded that learning motivation variable and parents' socioeconomic status had a significant influence. From the F-test statistic, it could be seen that $F_{\text {test }}$ higher compared to $F_{\text {table }}$ which was $60.426>3.23$. Thus, it was known that there was influence of learning motivation and parents' socio-economic status on the students' interest to continue study in master degree.

Coefficient of determination simultaneous test (R2) of learning motivation and parents' socio-economic status affected the tailed variable for $64.0 \%$ and the rest for $36.0 \%$ affected by other factors. Thus, it could be concluded that learning motivation and parents' socio-economic status simultaneously would affect the students' interest to continue studyin master degree of Education Administration Study Program in Jambi University.

The result of this research was in line with the research conducted by Farmesa, Hasmunir, \& Abdi (2017), the hypothesis test showed that $F_{\text {test }}>F_{\text {table }}$ or $33.88 \%>3.21$ which meant that there was a positive and significant influence of learning motivation and parents' socio-economic status on dependent variable which was the students' interest to continue study. Then a research from Suciningrum \& Rahayu (2015) showed the result of hypothesis test in which $F_{\text {-test }}$ was known for $F_{\text {test }}$ (52.893) $F_{\text {table }}$ (3.10). It could be concluded that the independent variables namely learning motivation and parents' socioeconomic status simultaneously influenced the students' interest to continue study. The implication of this research result has proven that there was positive and significant influence of learning motivation and parents' socio-economic status on the students' interest to continue study in master degree. It was shown that the high parents' socioeconomic status and learning motivation leaded to higher interest to continue study in master degree and vice versa. Hence, parents and people around the students should give such an encouragement to increase the students' learning motivation in order to expand their insight in particular and improve the quality of human resources in general.

This research obviously had limitations and weaknesses. The limitations would only be overcome in subsequent research, those were: a) The results of this study were limited to the Education Administration Study Program of Teacher Training and Education Faculty in Jambi University and could not be generalized to other study programs, b) data were analyzed based on the responses of respondents and were submitted in form of a questionnaire. The respondents' answers did not necessarily reflect the actual situation and would be different if the data were obtained by interview or direct observation, 3) the number of samples in this research were 71 respondents. There were still other independent variables that were assumed to influence the students' interest to continue study in master degree but had not been included in this research. 


\section{CONCLUSION}

According to the research results, these were the following conclusions: (a) There was influence of learning motivation on the students' interest to continue study in master degree for 0.559 with a significance value of 0.000 ; (b) There was influence of parents' socioeconomic status on the students' interest to continue study in master degree for 0.705 with a significance value of 0.000 ; (c) There was influence of learning motivation and parents' socioeconomic status toward the students' interest to continue study in master degree proven by the significance value was lower than alpha or $0.000<0.05$. Then, it was found that Fvalue was greater than Ftable or 60.426> 3.23. Learning motivation (X1) and parents' socio-economic status (X2) contributed to the dependent variable for $64.0 \%$ and the rest $36.0 \%$ was influenced by other factors.

Through this research, it was suggested that: (a) Academics should improve the quality of human resources for the students in order to ease job acquisition and be financially independent. As such, for those who want to continue their study to master's degree will not have to burden their parents. (b) Students should motivate themselves to study because motivation comes from self-awareness then we will realize that how education matters for the sake of their future. (c) Further research needs to be carried out regarding on other factors that also influence students' interest in continuing studies to master degree and it should be conducted by linking other variables or different samples and instruments. (d) The University should continue the efforts that have been made, so that bachelor degree graduates of Education Administration Program Study will increase their students who will likely to continue their studies to the master degree. In addition, it is expected that the university could increase socialization and promotion regarding the importance of continuing education and quality in the world of work in order to increase the interest of students in education administration to continue their education to a master degree.

\section{REFERENCES}

Creswell, J. W., \& Guetterman, T. C. (2018). Educational Research: Planning, Conducting, and Evaluating Quantitative and Qualitative Research. In Educational Research. https://doi.org/https://doi.org/10.1017/CB09781107415324.004.

Darmawan, D. (2014). Metode Penelitian Kuantitatif. Bandung: Remaja Rosdakarya.

Ekpo, T. E., \& Ajake, U. E. (2013). Family Socio-Economic Status and Delinquency among Senior Secondary School Students in Calabar South, Cross River State, Nigeria. American International Journal of Contemporary Research, 3(4), 83-88. http://www.aijcrnet.com/journals/Vol_3_No_4_April_2013/9.pdf. 
Farmesa, Y., Hasmunir, \& Abdi, A. W. (2017). Pengaruh Motivasi Belajar dan Status Sosial Ekonomi Orang Tua Terhadap Minat Melanjutkan Studi Ke Perguruan Tinggi Siswa Kelas XI SMAN 1 Simeulue Cut. Jurnal Ilmiah Mahasiswa Pendidikan Geografi FKIP Unsyiah, 2(2), 1-14. https://journal.unnes.ac.id/sju/index.php/eeaj/article/view/4702/4339.

Fitriani, K. (2013). Pengaruh Motivasi, Prestasi Belajar, Status Sosial Ekonomi Orang Tua Dan Lingkungan Sekolah Terhadap Minat Melanjutkan Pendidikan Ke Perguruan Tinggi Pada Siswa Kelas XII Akuntansi SMK Negeri 1 Kendal. Economic Education Analysis Journal, 3(1), 152-159. https://journal.unnes.ac.id/sju/index.php/eeaj/article/view/4229/3897.

Gerungan. (2009). Psikologi Sosial. Bandung: PT. Refika Aditama.

Hanifah, N., Rusdarti, \& Pujiati, A. (2018). The Effect of Socio-Economic of Family and Future Orientation Through Self-Motivation Towards the Interest in Continuing to the College of the Twelfth Grade Students of State Senior High Schools in Brebes Regency. Journal of Economic Education, 7(2), 94-100. https://doi.org/10.15294/JEEC.V7I2.26688.

Idi, A. (2010). Sosiologi Pendidikan. Jakarta: Raja Grafindo Persada.

Jumarin, M. (1994). Pendidikan Kejuruan. Jakarta: Bina Karya.

Khairani, M. (2013). Psikologi Belajar. Yogyakarta: Aswaya Pressindo.

Kharisma, N., \& Latifah, L. (2015). Pengaruh Motivasi, Prestasi Belajar, Status Sosial Ekonomi Orang Tua dan Lingkungan Teman Sebaya terhadap Minat Melanjutkan Pendidikan Ke Perguruan Tinggi pada Siswa Kelas XII Kompetensi Keahlian Akuntansi di SMK Negeri Se-Kota Semarang Tahun Ajaran 2014. Economic Education Analysis Journal, 4(3). https://journal.unnes.ac.id/sju/index.php/eeaj/article/view/8524.

Markum, M. (2007). Pendidikan Tinggi dalam Perspektif Sejarah dan Perkembangannya di Indonesia. Jakarta: UI-Press.

Muspawi, M., \& Claudia, P. R. (2018). Optimalisasi Pemanfaatan Sarana dan Prasarana Belajar di SMA Swasta Pelita Raya Kota Jambi. Jurnal Sains Sosio Humaniora, 2(2), 180-192. https://doi.org/10.22437/jssh.v2i2.5935.

Prasetyo, B., \& Jannah, L. M. (2014). Metode Penelitian Kuantitatif: Teori dan Aplikasi. Jakarta: Rajawali Pers.

Suciningrum, N. P., \& Rahayu, E. S. (2015). Pengaruh Status Sosial Ekonomi Orang Tua Dan Motivasi Belajar Tehadap Minat Melanjutkan Studi Ke Perguruan Tinggi Pada Kelas Xi Di Sma Pusaka 1 Jakarta. Jurnal Pendidikan Ekonomi Dan Bisnis (JPEB), 3(1), 1. https://doi.org/10.21009/jpeb.003.1.1.

Sugiyono. (2016). Metode penelitian pendidikan pendekatan kualitatif, kuantitatif, dan $R \&$ D. Bandung: Alfabeta. 
Sunarno, M. I. (2017). The Effect of Motivation, School Grades and the Level of Parent'S Education on the Interest of Taking Higher Degree Study. Eurasian Journal of Social Sciences, 5(4), 7-16. https://doi.org/10.15604/ejss.2017.05.04.002.

Umma, I., \& Margunani. (2015). Pengaruh Motivasi Belajar, Prestasi Belajar, dan Kondisi Ekonomi Keluarga terhadap Minat Siswa Melanjutkan Pendidikan ke Perguruan Tinggi Kelas XI IPS di SMA Negeri Sekecamatan Ngaliyan, Semarang. Economic Education Analysis Journal, 4(1), 242-249. https://journal.unnes.ac.id/sju/index.php/eeaj/article/view/4702/4339. 